\title{
Plasminogen activator inhibitor-1 4G/5G polymorphism is associated with metabolic syndrome parameters in Malaysian subjects
}

\author{
Zaid H. Al-Hamodi, ${ }^{1, *}$ Riyadh Saif-Ali, ${ }^{1,2}$ Ikram S. Ismail, ${ }^{3}$ Khaled A. Ahmed ${ }^{4}$ and Sekaran Muniandy ${ }^{1, *}$ \\ 'Department of Molecular Medicine, Faculty of Medicine and ${ }^{3}$ Department of Medicine, University of Malaya Medical Centre, University of Malaya, \\ 50603 Kuala Lumpur, Malaysia \\ ${ }^{2}$ Department of Biochemistry, Faculty of Medicine, Sana'a, Yemen \\ ${ }^{4}$ Faculty of Dentistry, Ibb University, Yemen
}

The plasminogen activator inhibitor-1 4G/5G and tissue plasminogen activator Alu-repeat insertion/deletion polymorphisms might be genetic determinations of increased or decreased of their plasma activities. The aim of this study was to investigate the association of plasminogen activator inhibitor-1 4G/5G and tissue plasminogen activator Alu-repeat I/D polymorphisms with metabolic syndrome parameters in normal Malaysian subjects and to assess the impact of these polymorphisms on their plasma activities and antigens. The genetic polymorphisms were genotyped in $\mathbf{1 3 0}$ normal subjects. In addition, the plasma activities and antigens of plasminogen activator inhibitor- 1 and tissue plasminogen activator as well as levels of insulin, glucose, and lipid profile at fasting state were investigated. The subjects with homozygous 4G/4G showed association with an increased triglyceride $(p=0.007)$, body mass index $(p=0.01)$ and diastolic blood pressure $(p=0.03)$. In addition, the plasminogen activator inhibitor1 4G/5G polymorphism modulates plasma plasminogen activator inhibitor-1 activity and antigen and tissue plasminogen activator activity $(p=0.002,0.014,0.003)$ respectively. These results showed that, the plasminogen activator inhibitor-1 4G/5G polymorphism is associated with metabolic syndrome parameters, plasminogen activator inhibitor-1 and tissue plasminogen activator activities in Malaysian subjects, and may serve to increase the risk of type 2 diabetes and cardiovascular disease in Malaysian subjects.

Key Words: plasminogen activator inhibitor-1, tissue plasminogen activator, type 2 diabetes, metabolic syndrome, cardiovascular disease

$\mathrm{C}$ entral obesity, hyperglycaemia, hyperinsulinemia, high triglycerides (TG), low levels of high-density lipoprotein cholesterol (HDL-c), hypertension and endothelial dysfunction are well-documented risk factors for type 2 diabetes (T2D), atherosclerosis and cardiovascular disease (CVD). ${ }^{(1,2)}$ The constellation of these metabolic abnormalities known as a metabolic syndrome (MetS) or insulin resistance syndrome increases the risk of T2D and CVD. The number of individuals with the MetS has increased globally during the past two decades, and this increase is associated with the worldwide epidemic of obesity and diabetes. ${ }^{(3)}$ High PAI-1 levels have been reported in obese and MetS subjects. ${ }^{(2,4)}$ Increase in plasma proinsulin, C-peptide and insulin, have also been associated with high levels of PAI-1. ${ }^{(5)}$

Plasma PAI-1 is the major physiological inhibitor of endogenous fibrinolysis. It inhibits the action of tissue plasminogen activator (tPA) and urokinase plasminogen activator (uPA), often leading to fibrin accumulation in basement membranes and interstitial tissues. ${ }^{(6-8)}$ Elevation in plasma PAI-1 appears to compromise normal fibrin clearance mechanisms and promotes thrombosis.

Several SNPs in the PAI-1 gene have been identified, ${ }^{(9)}$ among which the $4 \mathrm{G} / 5 \mathrm{G}$ polymorphism (rs1799889) located in the promoter region $-675 \mathrm{bp}$ upstream from the mRNA synthesis initiation point has been quite extensively studied. Association of this polymorphism and variables related to the MetS were, however, unclear which carriers of the $4 \mathrm{G}$ allele being more prone to obesity and MetS in some studies ${ }^{(9-11)}$ but not in others. ${ }^{(12-14)}$

Alu repeat I/D polymorphism was found in intron 8 of the tPA gene. ${ }^{(15)}$ This Alu repeats probably arose early in human evolution, and a number of populations have been found to be dimorphic for its presence or absence of repeats. ${ }^{(16)}$ This polymorphism, however, not significantly correlated with basal endothelial tPA synthesis. ${ }^{(17)}$

The PAI-1 4G/5G and tPA polymorphisms and their role in modulating plasma levels of PAI-1 and tPA activities and antigens have not been reported in Malaysian subjects. We studied the association of PAI-1 4G/5G and tPA polymorphisms with MetS parameters and plasma levels of PAI-1 and tPA activities and antigens in normal Malaysian subjects.

\section{Materials and Methods}

Subjects and data collection. In this study, normal subjects without diabetes and MetS in the Klang Valley, Kuala Lumpur were recruited. The study was approved by the Medical Ethics Committee of University Malaya Medical Centre. Written informed consent was obtained from each subject. Blood pressure (BP) measurements were taken from each subject's right arm in the seated position by using an Omron IntelliSense Automatic Blood Pressure Monitor after $10 \mathrm{~min}$ of rest in a quiet room in the morning. Between two and three successive BP readings were obtained at 5-min intervals and averaged. Body weight and height were measured and BMI was computed as weight (kg) divided by height $\left(\mathrm{m}^{2}\right)$. Waist circumference was measured midway between the lower rib margin and the superior iliac spine at the end of gentle expiration in a standing position.

Fasting venous blood $(10 \mathrm{ml})$ was collected from each subject within a $2 \mathrm{~h}$ window (8:00 to 10:00 AM) after 15 min rest, because of the diurnal variation of plasma PAI-1.(18) The collected blood immediately taken into five labelled Vacutainer tubes, $0.109 \mathrm{M}$

*To whom correspondence should be addressed.

E-mail: sekaran@um.edu.my; zalhamodi@yahoo.com 
trisodium citrate (for tPA and PAI-1 antigens and PAI-1/tPA complex analysis), acidified $0.5 \mathrm{M}$ sodium citrate (for tPA and PAI-1 activities), sodium fluoride (for glucose measurement), plain (for insulin and lipid profile) and K2 EDTA tubes (for genetic analysis). The plasma/serum was separated gently within 30 min by using Allerga R X-12R centrifuge (Beckman Coulter. Inc., Fullerton, CA) for a $15 \mathrm{~min}$ at $2,500-3,000 \times \mathrm{g}$ at $4^{\circ} \mathrm{C}$, aliquoted into corresponding micro tubes and immediately kept at $-80^{\circ} \mathrm{C}$ until analysis.

Biochemical analyses. Serum TG, HDL-c and plasma glucose were measured by an automated analyzer Dimension ${ }^{\circledR}$ RxL Max $^{\circledR}$ Integrated Chemistry System (Siemens Healthcare Diagnostics Inc., Deerfield, IL). Insulin was measured by ADVIA Centaur assay XP Immunoassay System (Siemens Healthcare Diagnostics Inc., Deerfield, IL). Investigations were done at Clinical Diagnostic Laboratory of the University Malaya Medical Centre (UMMC), Kuala Lumpur. Insulin resistance (IR) and Insulin sensitivity (IS) were calculated using the Homeostasis Model Assessment (HOMA2) Calculator v2.2 which is available from Oxford Centre for Diabetes, Endocrinology and Metabolism.

Plasma PAI-1 antigen was measured by TintElize ${ }^{\circledR}$ PAI-1 antigen ELISA test from Biopool (Trinity Biotech Inc. Jamestown, NY). PAI-1 activity, tPA activity and antigen and tPA/PAI-1complex were measured by PAI-1 activity, tPA activity, tPA total antigen, tPA/PAI-1 complex human assays respectively, (Molecular Innovations, Inc. Peary Court, Novi, MI) according to the manufacturer's instructions. Plates were read at $450 \mathrm{~nm}$ except the PAI-1 antigen plate which was at $490 \mathrm{~nm}$ using a microplate reader (BioRad, Calabasas, CA).

\section{Genetic analysis}

DNA extraction. Leukocyte genomic DNA was extracted from whole EDTA blood using a commercially Wizard ${ }^{\circledR}$ Genomic DNA Purification Kit (Promega Corporation, Madison, WI) according to the manufacturer's instructions.

Genotyping of PAI-1 polymorphisms. Allele specific PCR was used to detect the genotypes of PAI-1 4G/5G. Two specific forward allele primers (5G, 5'-GAGTCTGGACACGTGGGGG-3' at 3 ' end is G and 4G, 5'-GAGTCTGGACACGTGGGGA-3 at 3' end the 5 th $\mathrm{G}$ was replaced by $\mathrm{A}$ as matching the subsequent sequence) were designed to detect this SNP. An internal control is necessary to ensure that there was PCR amplification in each reaction. Therefore, common forward (upstream of allele specific primers 5'-TGGTCCCGTTCAGCCACCA-3') and reverse primers (downstream of allele specific primers 5'-ATGCAGCCAGCCACGTGAT-3') were used as PCR amplification controls with each $\mathrm{PCR}$ reaction. The reverse primer also is a reverse primer for the two allele specific primers.

Amplification reactions of PAI-1 were performed in two separated PCR reactions using $20 \mu \mathrm{l}$ volume of PCR contained $50 \mathrm{ng}$ of genomic DNA, 5 pmol of allele specific primer $5 \mathrm{G}$ or $4 \mathrm{G}$, 1.2 pmol of forward primer, 5 pmol of reverse primer, $1.5 \mathrm{mM}$ $\mathrm{MgCl} 2,1 \mathrm{X}$ PCR buffer, 1X Q-Solution, $100 \mu \mathrm{M}$ dNTPs and 0.5 unit of HotStarTaq Plus DNA Polymerase (Qiagen, Valencia, CA). DNA was denaturated at $94^{\circ} \mathrm{C}$ for $5 \mathrm{~min}$, followed by 25 cycles of denaturation at $94^{\circ} \mathrm{C}$ for $1 \mathrm{~min}$, annealing at $63^{\circ} \mathrm{C}$ for $45 \mathrm{~s}$, and extension at $70^{\circ} \mathrm{C}$ for $75 \mathrm{~s}$, with a final extension step for $5 \mathrm{~min}$ at $72^{\circ} \mathrm{C}$. The PCR products were run by electrophoresis in a $7 \%$ polyacrylamide gel (PAGE) and stained with ethidium bromide (EtBr). Band was visualized by the gel document system (Infinity 3026, Vilber Lourmat, Marnela Valled, France). Some of the PCR products were sent for sequencing Bioneer Corporation (Daedeok-gu, Daejeon, South Korea) to confirm the obtained results.

Genotyping of tPA polymorphisms. An I/D polymorphism resulting from the presence or absence of Alu repeats in intron 8 of the tPA gene was assessed by PCR using the following primers. ${ }^{(19)}$ Sense primer: 5'-GTGAAAAGCAAGGTCTACCAG-3' and nonsense primer: 5'-GACACCGAGTTCATCTTGA-C-3'. PCR reac- tion was performed in a $20 \mu \mathrm{l}$ volume with $10 \mathrm{pmol}$ of each primer, $200 \mu \mathrm{M}$ dNTP, $3 \mathrm{mM} \mathrm{MgCl}$, 1X PCR buffer, 1X Q-Solution, 1 unit HotStarTaq Plus DNA polymerase and 50 ng genomic DNA. The samples were initially denaturated at $94^{\circ} \mathrm{C}$ for $5 \mathrm{~min}$ before subjected to 30 cycles consisting of $1 \mathrm{~min}$ at $94^{\circ} \mathrm{C}$ (denaturation), $1 \mathrm{~min}$ at $60^{\circ} \mathrm{C}$ (annealing) and $75 \mathrm{~s}$ at $71^{\circ} \mathrm{C}$ (extension) in a thermal cycler followed by final extension at $72^{\circ} \mathrm{C}$ for $10 \mathrm{~min} .9 \mu \mathrm{l}$ of each product were electrophoresed on a $1 \%$ agarose gel, then stain by $\mathrm{EtBr}$ and visualized by the gel document system. To confirm the results, some of PCR products were sent to Bioneer Corporation (Daedeok-gu, Daejeon, South Korea) for sequencing.

Statistical analyses. Calculator to determine whether observed genotype frequencies are consistent with HardyWeinberg equilibrium (HW) was done by the method of Court $(2005,2008)$. The other statistical analyses were done by SPSS 11.5 (Social Package of Statistical Science) computer program by LEAD Technologies; Inc., Chicago, IL). The missing data were listwise deleted (when any of the variables were missing, the entire observation was omitted from the analysis). The BMI, waist, systolic blood pressure (SBP) and diastolic blood pressure (DBP), TG, HDL-c, FBS, insulin, IS, IR, tPA antigen and activity, PAI-1 antigen and activity, and tPA/PAI-1 complex were log transformed because they were not normally distributed. These parameters means and $95 \%$ confidence intervals were transformed back and reported as geometric means. The association of genetic Polymorphisms of PAI-1 and tPA with metabolic syndrome parameters; (BMI, waist, SBP, DBP, TG, HDL-c, FBS, insulin, IS and IR) and fibrinolytic PAI-1 and tPA activities and antigens, and $\mathrm{TPA} / \mathrm{PAI}-1$ complex (dependent variables) were analysed by univariate analyses (general linear model) adjusted for age, gender and race as covariates. The difference between means was considered significant if the $p$ value $<0.05$.

\section{Results}

Of five hundred normal respondents, 190 were recruited for the study. After biochemical tests and application of IDF criteria for MetS diagnosis, ${ }^{(20)} 130$ of those were revealed as normal without overt diabetes or MetS. The biochemical and clinical parameters of the subjects are shown in Table 1. In general, univariate tests

Table 1. Biochemical and clinical parameters among subjects

\begin{tabular}{llc}
\hline Parameters & & Value \\
\hline Gender \% & Male/Female & $34.6 / 65.4$ \\
Races \% & Malay & 52.3 \\
& Chinese & 33.8 \\
& Indian & 13.8 \\
Age (yrs) & & $49.1 \pm 12.57$ \\
Body mass index (kg/m²) & $23.0 \pm 3.76$ \\
Waist circumference $(\mathrm{cm})$ & $79.9 \pm 11.01$ \\
Diastolic blood pressure $(\mathrm{mmHg})$ & & $80.4 \pm 8.97$ \\
Systolic blood pressure $(\mathrm{mmHg})$ & $131.8 \pm 18.30$ \\
Triglyceride (mmol/l) & $1.1 \pm 0.56$ \\
High density lipoprotein $(\mathrm{mmol} / \mathrm{l})$ & & $1.6 \pm 0.37$ \\
Low density lipoprotein $(\mathrm{mmol} / \mathrm{l})$ & & $3.2 \pm 0.88$ \\
Fasting blood glucose $(\mathrm{mmol} / \mathrm{l})$ & & $5.0 \pm 0.51$ \\
Insulin (pmol/l) & & $1.0 \pm 0.66$ \\
Insulin resistance (IR) & & $15.5 \pm 8.90$ \\
PAl-1 activity (IU/ml) & $34.8 \pm 18.96$ \\
PAl-1 antigen (ng/ml) & $3.3 \pm 2.95$ \\
tPA activity (U/ml) & $4.4 \pm 2.87$ \\
tPA antigen (ng/ml) & $5.0 \pm 3.05$ \\
tPA/PAl-1 complex (ng/ml) & & \\
\hline
\end{tabular}

The result presented as mean \pm SD. Number of subjects $=130$. 
Table 2. Association of PAl-1 polymorphism with metabolic syndrome parameters among subjects

\begin{tabular}{|c|c|c|c|c|c|c|}
\hline \multirow[b]{2}{*}{ Metabolic syndrome parameter } & \multicolumn{6}{|c|}{ PAI-1 polymorphism } \\
\hline & $\begin{array}{l}5 \mathrm{G} / 5 \mathrm{G} \\
n(37)\end{array}$ & $\begin{array}{l}4 G / 5 G \\
n(63)\end{array}$ & $\begin{array}{l}4 \mathrm{G} / 4 \mathrm{G} \\
n(30)\end{array}$ & $\begin{array}{l}\text { Univariat } \\
p \text { value }\end{array}$ & $\begin{array}{c}4 \mathrm{G} / 4 \mathrm{G} \text { vs } 5 \mathrm{G} / 5 \mathrm{G} \\
p \text { value }\end{array}$ & $\begin{array}{c}4 \mathrm{G} / 5 \mathrm{G} \text { vs } 5 \mathrm{G} / 5 \mathrm{G} \\
p \text { value }\end{array}$ \\
\hline Body mass index $\left(\mathrm{kg} / \mathrm{m}^{2}\right)$ & $\begin{array}{c}21.3 \\
(20.4-22.3)\end{array}$ & $\begin{array}{c}22.4 \\
(21.7-23.2)\end{array}$ & $\begin{array}{c}23.2 \\
(22.1-24.4)\end{array}$ & 0.032 & 0.01 & 0.08 \\
\hline Waist circumference $(\mathrm{cm})$ & $\begin{array}{c}77.1 \\
(74.8-79.4)\end{array}$ & $\begin{array}{c}78.4 \\
(76.7-80.3)\end{array}$ & $\begin{array}{c}78.0 \\
(75.3-80.8)\end{array}$ & 0.66 & 0.61 & 0.34 \\
\hline Diastolic blood pressure $(\mathrm{mmHg})$ & $\begin{array}{c}77.5 \\
(75.3-79.7)\end{array}$ & $\begin{array}{c}80.4 \\
(78.7-82.2)\end{array}$ & $\begin{array}{c}81.2 \\
(78.6-83.9)\end{array}$ & 0.056 & 0.03 & 0.008 \\
\hline Systolic blood pressure $(\mathrm{mmHg})$ & $\begin{array}{c}127 \\
(123-132)\end{array}$ & $\begin{array}{c}129 \\
(125-132)\end{array}$ & $\begin{array}{c}133 \\
(128-138)\end{array}$ & 0.23 & 0.096 & 0.62 \\
\hline Triglyceride (mmol/l) & $\begin{array}{c}0.92 \\
(0.80-1.03)\end{array}$ & $\begin{array}{c}1.04 \\
(0.95-1.14)\end{array}$ & $\begin{array}{c}1.17 \\
(1.03-1.33)\end{array}$ & 0.026 & 0.007 & 0.099 \\
\hline T-cholesterol (mmol/l) & $\begin{array}{c}4.97 \\
(4.72-5.24)\end{array}$ & $\begin{array}{c}5.32 \\
(5.11-5.54)\end{array}$ & $\begin{array}{c}5.21 \\
(4.90-5.53)\end{array}$ & 0.14 & 0.26 & 0.047 \\
\hline HDL-cholesterol (mmol/l) & $\begin{array}{c}1.62 \\
(1.52-1.72)\end{array}$ & $\begin{array}{c}1.52 \\
(1.46-1.59)\end{array}$ & $\begin{array}{c}1.51 \\
(1.41-1.61)\end{array}$ & 0.21 & 0.12 & 0.13 \\
\hline LDL-cholesterol (mmol/l) & $\begin{array}{c}2.90 \\
(2.66-3.16)\end{array}$ & $\begin{array}{c}3.27 \\
(3.07-3.49)\end{array}$ & $\begin{array}{c}3.00 \\
(2.71-3.30)\end{array}$ & 0.07 & 0.64 & 0.03 \\
\hline Fasting blood sugar (mmol/l) & $\begin{array}{l}5.01 \\
(4.9-5.15)\end{array}$ & $\begin{array}{c}4.97 \\
(4.87-5.08)\end{array}$ & $\begin{array}{c}4.93 \\
(4.77-5.09\end{array}$ & 0.75 & 0.45 & 0.69 \\
\hline Insulin (pmol/l) & $\begin{array}{c}39.9 \\
(34.3-46.4)\end{array}$ & $\begin{array}{c}43.7 \\
(38.8-49.1)\end{array}$ & $\begin{array}{c}46.9 \\
(39.3-55.8)\end{array}$ & 0.38 & 0.17 & 0.35 \\
\hline Insulin resistance & $\begin{array}{c}0.78 \\
(0.66-0.91)\end{array}$ & $\begin{array}{c}0.86 \\
(0.76-0.96)\end{array}$ & $\begin{array}{c}0.89 \\
(0.74-1.06)\end{array}$ & 0.5 & 0.27 & 0.37 \\
\hline
\end{tabular}

The result presented as geometric mean and $95 \%$ confidence interval of the mean adjusted for age, gender and race as covariates which evaluated by univariate (General Linear Model). Number of subjects $=130$.

Table 3. Association of tPA Polymorphism with metabolic syndrome parameters among subjects

\begin{tabular}{|c|c|c|c|c|c|c|}
\hline \multirow[b]{2}{*}{ Metabolic syndrome parameter } & \multicolumn{6}{|c|}{ tPA polymorphism } \\
\hline & $\begin{array}{c}\mathrm{D} / \mathrm{D} \\
n(36)\end{array}$ & $\begin{array}{c}\text { I/D } \\
n(63)\end{array}$ & $\begin{array}{c}\mathrm{I} / \mathrm{I} \\
n(30)\end{array}$ & $\begin{array}{c}\text { Univariate } \\
p \text { value }\end{array}$ & $\begin{array}{c}\text { I/I vs } D / D \\
p \text { value }\end{array}$ & $\begin{array}{l}\text { I/D vs } D / D \\
p \text { value }\end{array}$ \\
\hline Body mass index $\left(\mathrm{kg} / \mathrm{m}^{2}\right)$ & $\begin{array}{c}22.1 \\
(21.1-23.2)\end{array}$ & $\begin{array}{c}22.4 \\
(21.7-23.2)\end{array}$ & $\begin{array}{c}22.0 \\
(21.0-23.0)\end{array}$ & 0.76 & 0.84 & 0.65 \\
\hline Waist circumference $(\mathrm{cm})$ & $\begin{array}{c}77.4 \\
(75.0-79.8)\end{array}$ & $\begin{array}{c}77.9 \\
(76.2-79.7)\end{array}$ & $\begin{array}{c}78.4 \\
(76.0-80.9)\end{array}$ & 0.83 & 0.45 & 0.72 \\
\hline Diastolic blood pressure $(\mathrm{mmHg})$ & $\begin{array}{c}79.7 \\
(77.3-82.2)\end{array}$ & $\begin{array}{c}79.0 \\
(77.2-80.9)\end{array}$ & $\begin{array}{c}80.6 \\
(78.0-83.3)\end{array}$ & 0.63 & 0.61 & 0.68 \\
\hline Systolic blood pressure $(\mathrm{mmHg})$ & $\begin{array}{c}133 \\
(128-138)\end{array}$ & $\begin{array}{c}129 \\
(126-132)\end{array}$ & $\begin{array}{c}128 \\
(124-133)\end{array}$ & 0.32 & 0.19 & 0.17 \\
\hline Triglyceride (mmol/l) & $\begin{array}{c}0.95 \\
(0.83-1.08)\end{array}$ & $\begin{array}{c}1.04 \\
(0.95-1.14)\end{array}$ & $\begin{array}{c}1.12 \\
(0.98-1.27)\end{array}$ & 0.2 & 0.07 & 0.25 \\
\hline T-cholesterol (mmol/l) & $\begin{array}{c}5.07 \\
(4.81-5.34)\end{array}$ & $\begin{array}{c}5.30 \\
(5.09-5.51)\end{array}$ & $\begin{array}{c}5.32 \\
(5.00-5.66)\end{array}$ & 0.35 & 0.9 & 0.19 \\
\hline HDL-cholesterol (mmol/l) & $\begin{array}{c}1.56 \\
(1.46-1.66)\end{array}$ & $\begin{array}{c}1.54 \\
(1.47-1.61)\end{array}$ & $\begin{array}{c}1.52 \\
(1.42-1.63)\end{array}$ & 0.86 & 0.59 & 0.69 \\
\hline LDL-cholesterol ( $\mathrm{mmol} / \mathrm{l})$ & $\begin{array}{c}3.02 \\
(2.77-3.28)\end{array}$ & $\begin{array}{c}3.18 \\
(2.98-3.39)\end{array}$ & $\begin{array}{c}3.17 \\
(2.87-3.50)\end{array}$ & 0.58 & 0.43 & 0.32 \\
\hline Fasting blood sugar (mmol/l) & $\begin{array}{c}4.96 \\
(4.82-5.10)\end{array}$ & $\begin{array}{c}4.98 \\
(4.88-5.08)\end{array}$ & $\begin{array}{c}5.02 \\
(4.87-5.17)\end{array}$ & 0.84 & 0.55 & 0.8 \\
\hline Insulin (pmol/l) & $\begin{array}{c}39.5 \\
(33.8-46.0)\end{array}$ & $\begin{array}{c}45.2 \\
(40.2-50.7)\end{array}$ & $\begin{array}{c}42.2 \\
(35.6-50.0)\end{array}$ & 0.39 & 0.56 & 0.17 \\
\hline Insulin resistance & $\begin{array}{c}0.78 \\
(0.66-0.92)\end{array}$ & $\begin{array}{c}0.89 \\
(0.79-1.00)\end{array}$ & $\begin{array}{c}0.83 \\
(0.69-0.98)\end{array}$ & 0.45 & 0.66 & 0.22 \\
\hline
\end{tabular}

The result presented as geometric mean and $95 \%$ confidence interval of the mean adjusted for age, gender and race as covariates which evaluated by univariate (General Linear Model). Number of subjects $=130$.

showed that the PAI-1 4G/5G variant was associated with BMI $(p=0.032)$ and TG $(p=0.026)$ but not-significantly associated with other MetS parameters (Table 2). On the other hand, the Pairwise Comparisons showed that the subjects carrying homozygous 4G/4G were had higher BMI $(p=0.01)$, DBP $(p=0.03)$ and TG $(p=0.007)$ than those with homozygous $5 \mathrm{G} / 5 \mathrm{G}$ genotype.
Furthermore, the DBP, TC and LDL-c were higher in the subjects with heterozygous $4 \mathrm{G} / 5 \mathrm{G}$ compared to those carrying the $5 \mathrm{G} / 5 \mathrm{G}$ genotype ( $p=0.008,0.047,0.03$ respectively). Univariate analyses showed that the IPA polymorphism was not associated with MetS parameters with $p$ value $>0.05$ (Table 3 ).

Univariate test, showed that, the PAI-1 4G/5G polymorphism 
Table 4. Association of PAl-1 polymorphisms with their plasma activities and antigens and tPA/PAI-1 complex among subjects

\begin{tabular}{|c|c|c|c|c|c|c|}
\hline \multirow[b]{2}{*}{ Parameters } & \multicolumn{6}{|c|}{ PAI-1 polymorphism } \\
\hline & $\begin{array}{l}5 G / 5 G \\
n(37)\end{array}$ & $\begin{array}{l}4 \mathrm{G} / 5 \mathrm{G} \\
n(63)\end{array}$ & $\begin{array}{l}\text { 4G/4G } \\
n(30)\end{array}$ & $\begin{array}{c}\text { Univariate } \\
p \text { value }\end{array}$ & $\begin{array}{c}4 \mathrm{G} / 4 \mathrm{G} \text { vs } 5 \mathrm{G} / 5 \mathrm{G} \\
p \text { value }\end{array}$ & $\begin{array}{c}4 \mathrm{G} / 5 \mathrm{G} \text { vs } 5 \mathrm{G} / 5 \mathrm{G} \\
p \text { value }\end{array}$ \\
\hline PAI-1 activity (IU/ml) & $\begin{array}{c}9.93 \\
(8.15-12.1)\end{array}$ & $\begin{array}{c}13.9 \\
(12.9-17.3)\end{array}$ & $\begin{array}{c}13.6 \\
(11.0-16.8)\end{array}$ & 0.002 & 0.03 & $4.6 \times 10^{-4}$ \\
\hline PAl-1 antigen (ng/ml) & $\begin{array}{c}25.8 \\
(22.2-30.1)\end{array}$ & $\begin{array}{c}33.6 \\
(30.0-37.6)\end{array}$ & $\begin{array}{c}34.1 \\
(29.0-40.1)\end{array}$ & 0.014 & 0.014 & 0.007 \\
\hline tPA activity (U/ml) & $\begin{array}{c}2.12 \\
(1.57-2.80)\end{array}$ & $\begin{array}{c}3.02 \\
(2.48-3.65)\end{array}$ & $\begin{array}{c}1.58 \\
(1.08-2.20)\end{array}$ & 0.003 & 0.12 & 0.04 \\
\hline tPA antigen (ng/ml) & $\begin{array}{c}3.49 \\
(2.77-4.36)\end{array}$ & $\begin{array}{c}3.51 \\
(2.95-4.15)\end{array}$ & $\begin{array}{c}4.41 \\
(3.42-5.62)\end{array}$ & 0.29 & 0.17 & 0.97 \\
\hline tPA/PAI-1 complex (ng/ml) & $\begin{array}{c}2.62 \\
(1.63-3.98)\end{array}$ & $\begin{array}{c}2.31 \\
(1.60-3.21)\end{array}$ & $\begin{array}{c}3.39 \\
(2.06-5.31)\end{array}$ & 0.44 & 0.43 & 0.66 \\
\hline
\end{tabular}

The result presented as geometric mean and $95 \%$ confidence interval of the mean adjusted for age, gender and race as covariates which evaluated by univariate (General Linear Model). Number of subjects $=130$.

Table 5. Association of tPA polymorphisms with their plasma activities and antigens and tPA/PAI-1 complex among subjects

\begin{tabular}{|c|c|c|c|c|c|c|}
\hline \multirow[b]{2}{*}{ Parameters } & \multicolumn{6}{|c|}{ tPA polymorphism } \\
\hline & $\begin{array}{c}\mathrm{D} / \mathrm{D} \\
n(36)\end{array}$ & $\begin{array}{c}\text { I/D } \\
n(63)\end{array}$ & $\begin{array}{c}\mathrm{l} / \mathrm{I} \\
n(30)\end{array}$ & $\begin{array}{c}\text { Univariate } \\
p \text { value }\end{array}$ & $\begin{array}{l}\text { I/I vs D/D } \\
p \text { value }\end{array}$ & $\begin{array}{l}\text { I/D vs D/D } \\
p \text { value }\end{array}$ \\
\hline PAI-1 activity (IU/ml) & $\begin{array}{c}12.5 \\
(10.3-15.1)\end{array}$ & $\begin{array}{c}14.7 \\
(12.6-17.1)\end{array}$ & $\begin{array}{c}14.6 \\
(11.7-18.3)\end{array}$ & 0.33 & 0.26 & 0.16 \\
\hline PAl-1 antigen (ng/ml) & $\begin{array}{c}34.5 \\
(29.3-40.4)\end{array}$ & $\begin{array}{c}32.3 \\
(28.4-36.8)\end{array}$ & $\begin{array}{c}28.3 \\
(23.9-33.6)\end{array}$ & 0.25 & 0.11 & 0.57 \\
\hline tPA activity (U/ml) & $\begin{array}{c}2.60 \\
(1.94-3.40)\end{array}$ & $\begin{array}{c}1.97 \\
(1.54-2.46)\end{array}$ & $\begin{array}{c}3.03 \\
(2.24-4.02)\end{array}$ & 0.06 & 0.45 & 0.14 \\
\hline tPA antigen (ng/ml) & $\begin{array}{c}3.93 \\
(3.11-4.92)\end{array}$ & $\begin{array}{c}3.74 \\
(3.10-4.48)\end{array}$ & $\begin{array}{c}3.33 \\
(2.54-4.28)\end{array}$ & 0.5 & 0.3 & 0.96 \\
\hline tPA/PAI-1 complex (ng/ml) & $\begin{array}{c}2.44 \\
(1.50-3.74)\end{array}$ & $\begin{array}{c}3.46 \\
(2.50-4.67)\end{array}$ & $\begin{array}{c}1.59 \\
(0.84-2.65)\end{array}$ & 0.04 & 0.23 & 0.21 \\
\hline
\end{tabular}

The result presented as geometric mean and $95 \%$ confidence interval of the mean adjusted for age, gender and race as covariates which evaluated by univariate (General Linear Model). Number of subjects $=130$.

was strongly associated with PAI-1 activity and antigen and tPA activity ( $p=0.002,0.014,0.003$ respectively) (Table 4$)$. On the other hand, the tPA Alu-repeat I/D polymorphism was associated with tPA/PAI-1 complex $(p=0.04)$ and weakly associated with the tPA activity $(p=0.06)$. The tPA Alu-repeat I/D polymorphism was not associated with PAI-1 and tPA antigens or PAI-1 activity (Table 5).

Pairwise comparison indicated that the PAI-1 activity and antigen was higher in subjects having homozygous $4 \mathrm{G} / 4 \mathrm{G}(p=$ $0.03,0.014$ respectively), or heterozygous $4 \mathrm{G} / 5 \mathrm{G}\left(p=4.6 \times 10^{-4}\right.$, 0.007 respectively), than those carrying homozygous $5 \mathrm{G} / 5 \mathrm{G}$. In contrast, the tPA activity was lower in subjects having homozygous $4 \mathrm{G} / 4 \mathrm{G}$ or heterozygous $4 \mathrm{G} / 5 \mathrm{G}$ of $\mathrm{PAI}-1$ polymorphism than those with homozygous $5 \mathrm{G} / 5 \mathrm{G}(p=0.12,0.04)$.

Univariate analysis showed that the homozygous $\mathrm{I} / \mathrm{I}$ and $\mathrm{D} / \mathrm{D}$ as well as homozygous $\mathrm{D} / \mathrm{D}$ and heterozygous I/D of tPA polymorphism were not associated with fibrinolytic PAI-1 and tPA activities and antigens and the levels of tPA/PAI-1 complex (Table 5).

\section{Discussion}

The association of PAI-1 4G/5G and tPA Alu-repeat I/D polymorphisms with MetS parameters was assessed in normal Malaysian subjects. The impact of these polymorphisms on PAI-1 and tPA activities and levels were also evaluated. The homozygous PAI-1 4G/4G genotype showed significant association with MetS parameters; plasma TG, BMI and DBP. Hoffstedt et al. ${ }^{(13)}$ had linked this variant with obesity. However, the mechanism by which polymorphisms in the PAI-1 promoter affect MetS parameters is not known.

The risk of MetS is notably higher in $4 \mathrm{G}$ carriers since it is associated with elevated plasma PAI-1 and reduced tPA activities. This finding is in agreement with previous studies reporting a similar association between the PAI-1 4G variant and increased risk of T2D and MetS in 1272 healthy employees in southern Italy and 210 Caucasian subjects, ${ }^{(21,22)}$ and high levels of fibrinolytic PAI-1 and tPA. ${ }^{(23)}$ The PAI-1 5G allele contains an additional binding site for a DNA-binding protein that is thought to play a pivotal role as a repressor during transcription. ${ }^{(24,25)}$ The binding of the transcriptional repressor may decrease the binding of transcriptional activator ${ }^{(26)}$ and this may explain why PAI-1 4G alleles have higher PAI-1 activity. A deletion allele (4G) in the PAI-1 promoter raises PAI-I activity. ${ }^{(27,28)}$ The PAI-1 activity and antigen are expected to be higher in homozygous $4 \mathrm{G} / 4 \mathrm{G}$ than heterozygous $4 \mathrm{G} / 5 \mathrm{G}$ individuals. However, there are no significant differences in both PAI-1 activity and antigen between $4 \mathrm{G} / 5 \mathrm{G}$ and 4G/4G ( $p=0.33,0.88$ respectively). This may be interpreted to mean PAI-1 mono-allelic expression in $4 \mathrm{G} / 5 \mathrm{G}$ individuals. Allelic variation in gene expression is common in the human genome. ${ }^{(29-31)}$ In addition, genomic and epigenetic changes in PAI-1 may also affect overall PAI-1 expression.

Sternlicht et al. ${ }^{(32)}$ summarized the published data about levels and activity of PAI-1 among different populations carrying the PAI-1 5G/5G, 4G/5G and 4G/4G genotypes. The results showed a discrepancy in the levels and activity of PAI-1 among different 
populations. Our results were similar to that found in Chinese's men. ${ }^{(33)}$

Plasma levels of PAI-1 are determined by both environmental and genetic factors. Although the regulation of PAI- 1 is multifactorial in nature, the influence of genetic factors cannot be excluded. There has been a growing interest in the influence of genetic variation within the PAI-1 gene on plasma PAI-1 concentrations, ${ }^{(34,35)}$ and the difference in PAI-1 levels between $4 \mathrm{G}$ and $5 \mathrm{G}$ are more apparent in the presence of environmental and/or disease factors, which stimulate PAI-1 expression. ${ }^{(36)}$ However, the interactions of genetic and environmental determinants on PAI-1 expression are not fully understood.

MetS is a multifactorial and polygenic entity in which the fibrinolytic system has been shown to be implicated. It has been reported that there was a clear trend toward increasing PAI-1 activity with increased insulin resistance, waist circumference, BMI, and decreased HDL-c. ${ }^{(1)}$ Studies on the genetic input on body fat distribution has demonstrated that $56 \%$ of the variance in abdominal visceral fat mass was due to genetic factors. ${ }^{(37)}$ High PAI-1 activity has been reported to be associated with cardiovascular events. ${ }^{(38,39)}$ Meta analysis has shown that PAI-1 4G/5G polymorphism contributed to cardiovascular, ischemic stroke and venous thromboembolism risk $^{(40-42)}$ and $20 \%$ increased risk of myocardial infarction. ${ }^{(43)}$ However, treatment by the PAI-1 inhibitors improved histological remodeling of myocardium and arteries with suppression of inflammation and thrombus format. ${ }^{(4)}$

The association of tPA I/D polymorphism with MetS was not-significant. This is in agreement with previous studies demonstrating a lack of association between the tPA gene and hypertension, a MetS parameter in Chinese $\operatorname{Han}^{(45)}$ and Korean populations. ${ }^{(19)}$ Hence, this variation in the tPA gene may not be appropriate for prediction of MetS.

\section{Conclusion}

The PAI-1 4G/5G polymorphism is associated with MetS parameters; BMI, TG, and blood pressure which may increase the risk of MetS and T2D and CVD in Malaysian subjects. The impaired fibrinolytic activity of PAI-1 and tPA is well known risk factor for T2D and CVD and this association might indicate modulation by PAI-1 4G/5G polymorphism.

\section{References}

1 Al-Hamodi Z, Ismail IS, Saif-Ali R, Ahmed KA, Muniandy S. Association of plasminogen activator inhibitor- 1 and tissue plasminogen activator with type 2 diabetes and metabolic syndrome in Malaysian subjects. Cardiovasc Diabetol 2011; 10: 23.

2 Eckel RH, Grundy SM, Zimmet PZ. The metabolic syndrome. Lancet 2005; 365: 1415-1428.

3 Zimmet PA, Alberti KG, Shaw J. Global and societal implications of the diabetes epidemic. Nature 2001; 414: 782-787.

4 Alessi MC, Juhan-Vague I. PAI-1 and the metabolic syndrome: links, causes, and consequences. Arterioscler Thromb Vasc Biol 2006; 26: 2200-2207.

5 Anna Ågren. Mechanisms and effects of low plasminogen activator inhibitor type 1 activity. Stockholm: Published by Karolinska Institutet, 2008.

6 Dellas C, Loskutoff DJ. Historical analysis of PAI-1 from its discovery to its potential role in cell motility and disease. Thromb Haemost 2005; 93: 631640.

7 Kohler HP, Grant PJ. Plasminogen-activator inhibitor type 1 and coronary artery disease. $N$ Engl J Med 2000; 342: 1792-1801.

8 Lijnen HR. Pleiotropic functions of plasminogen activator inhibitor-1. $J$ Thromb Haemost 2005; 3: 35-45.

9 Lopes C, Dina C, Durand E, Froguel P. PAI-1 polymorphisms modulate phenotypes associated with the metabolic syndrome in obese and diabetic Caucasian population. Diabetologia 2003; 46: 1284-1290.

10 Juhan-Vague I, Morange PE, Frere C, et al. The plasminogen activator inhibitor-1 $-6754 \mathrm{G} / 5 \mathrm{G}$ genotype influences the risk of myocardial infarction

\section{Competing of Interests}

None declared.

\section{Author's Contributions}

Zaid Al-Hamodi collected data, performed practical and statistical analysis and drafted the manuscript; Riyadh Saif-Ali performed statistical analysis, helped drafting and edited the manuscript; Ikram S. Ismail helped in data collection and editing the manuscript; Khaled A. Ahmed helped in data collection. Sekaran Muniandy guided, supervised and edited the manuscript.

\section{Acknowledgment}

The authors wish to thank University of Malaya for supporting this research grant, Fundamental Research Grant Scheme (FRGS/ PS251/2010B).

\section{Abbreviations}

BMI body mass index

CHD coronary heart disease

CI confidence interval

CVD cardiovascular disease

DBP diastolic blood pressure

FBS fasting blood sugar

HDL-c high density lipoprotein cholesterol

HOMA (IR) homeostasis model assessment (insulin resistance)

IDF international diabetes federation

IS insulin sensitivity

MetS metabolic syndrome

PAI-1 plasminogen activator inhibitor-1

SBP systolic blood pressure

TG triglycerides

tPA tissue plasminogen activator

T2D type 2 diabetes

UMMC University Malaya medical centre

uPA urokinase plasminogen activator associated with elevated plasma proinsulin and insulin concentrations in men from Europe: the HIFMECH study. J Thromb Haemost 2003; 1: 2322-2329.

11 Mansfield MW, Stickland MH, Grant PJ. Environmental and genetic factors in relation to elevated circulating levels of plasminogen activator inhibitor-1 in Caucasian patients with non-insulin-dependent diabetes mellitus. Thromb Haemost 1995; 74: 842-847.

12 Freeman MS, Mansfield MW. To: Hoffsted et al. (2002) The common -675 $4 \mathrm{G} / 5 \mathrm{G}$ polymorphism in the plasminogen activator inhibitor-1 gene is strongly associated with obesity. Diabetologia 2002; 45: 1602-1603 author reply 1604.

13 Hoffstedt J, Andersson IL, Persson L, Isaksson B, Amer P. The common $-6754 \mathrm{G} / 5 \mathrm{G}$ polymorphism in the plasminogen activator inhibitor-1 gene is strongly associated with obesity. Diabetologia 2002; 45: 584-587.

14 Viitanen L, Pihlajamäki J, Halonen P, et al. Association of angiotensin converting enzyme and plasminogen activator inhibitor-1 promoter gene polymorphisms with features of the insulin resistance syndrome in patients with premature coronary heart disease. Atherosclerosis 2001; 157: 57-64.

15 Tishkoff SA, Ruano G, Kidd JR, Kidd KK. Distribution and frequency of a polymorphic Alu insertion at the plasminogen activator locus in humans. Hum Genet 1996; 97: 759-764.

16 Novick GE, Novick CC, Yunis J, et al. Polymorphic Alu insertions and the Asian origin of Native American populations. Hum Biol 1998; 70: 23-39.

17 van den Eijnden-Schrauwen Y, Lakenberg N, Emeis JJ, de Knijff P. Alu-repeat polymorphism in the tissue-type plasminogen activator (tPA) gene does not 
affect basal endothelial tPA synthesis. Thromb Haemost 1995; 74: 1202.

18 Alessi MC, Poggi M, Juhan-Vague I. Plasminogen activator inhibitor-1, adipose tissue and insulin resistance. Curr Opin Lipidol 2007; 18: 240-245.

19 Kang BY, Lee KO. Genetic polymorphisms of t-PA and PAI-1 genes in the Korean population. Korean J Biol Sci 2003; 7: 249-253.

20 Alberti KG, Zimmet P, Shaw J and IDF Epideminology Task Force Consensus Group. The metabolic syndrome- a new worldwide definition. Lancet 2005; 366: 1059-1062.

21 Anvari A, Schuster E, Gottsauner-Wolf M, Wojta J, Huber K. PAI-I 4G/5G polymorphism and sudden cardiac death in patients with coronary artery disease. Thromb Res 2001; 103: 103-107.

22 Margaglione M, Cappucci G, Colaizzo D, et al. The PAI-1 gene locus 4G/5G polymorphism is associated with a family history of coronary artery disease. Arterioscler Thromb Vasc Biol 1998; 18: 152-156.

23 Jastrzebska M, Goracy I, Naruszewicz M. Relationships between fibrinogen, plasminogen activator inhibitor-1, and their gene polymorphisms in current smokers with essential hypertension. Thromb Res 2003; 110: 339-344.

24 Dawson SJ, Wiman B, Hamsten A, Green F, Humphries S, Henney AM. The two allele sequences of a common polymorphism in the promoter of the plasminogen activator inhibitor-1 (PAI-1) gene respond differently to interleukin-1 in HepG2 cells. J Biol Chem 1993; 268: 10739-10745.

25 Grancha S, Estellés A, Tormo G, et al. Plasminogen activator inhibitor-1 (PAI-1) promoter $4 \mathrm{G} / 5 \mathrm{G}$ genotype and increased PAI- 1 circulating levels in postmenopausal women with coronary artery disease. Thromb Haemost 1999; 81: $516-521$.

26 Burzotta F, Di Castelnuovo A, Amore C, et al. 4G/5G promoter PAI-1 gene polymorphism is associated with plasmatic PAI-1 activity in Italians: a model of gene-environment interaction. Thromb Haemost 1998; 79: 354-358.

27 Eriksson P, Kallin B, van 't Hooft FM, Båvenholm P, Hamsten A. Allelespecific increase in basal transcription of the plasminogen-activator inhibitor 1 gene is associated with myocardial infarction. Proc Natl Acad Sci USA 1995; 92: 1851-1855.

28 Schneiderman J, Sawdey MS, Keeton MR, et al. Increased type 1 plasminogen activator inhibitor gene expression in atherosclerotic human arteries. Proc Natl Acad Sci USA 1992; 89: 6998-7002.

29 Lo HS, Wang Z, Hu Y, et al. Allelic variation in gene expression is common in the human genome. Genome Res 2003; 13: 1855-1862.

30 Palacios R, Gazave E, Goni J, et al. Allele-specific gene expression is widespread across the genome and biological processes. PLoS One 2009; 4: e4150.

31 Pant PV, Tao H, Beilharz EJ, Ballinger DG, Cox DR, Frazer KA. Analysis of allelic differential expression in human white blood cells. Genome Res 2006; 16: 331-339.

32 Sternlicht MD, Dunning AM, Moore DH, et al. Prognostic value of PAI1 in invasive breast cancer: evidence that tumor-specific factors are more important than genetic variation in regulating PAI1 expression. Cancer Epidemiol Biomarkers Prev 2006; 15: 2107-2114.

33 Jeng JR. Association of PAI-1 gene promoter $4 \mathrm{G} / 5 \mathrm{G}$ polymorphism with plasma PAI-1 activity in Chinese patients with and without hypertension. $\mathrm{Am}$ J Hypertens 2003; 16: 290-296.

34 Loskutoff DJ, Sawdey M, Keeton M, Schneiderman J. Regulation of PAI-1 gene expression in vivo. Thromb Haemost 1993; 70: 135-137.

35 Roncal C, Orbe J, Rodriguez JA, et al. Influence of the 4G/5G PAI-1 genotype on angiotensin II-stimulated human endothelial cells and in patients with hypertension. Cardiovasc Res 2004; 63: 176-185.

36 Hoekstra T, Geleijnse JM, Schouten EG, Kluft C. Plasminogen activator inhibitor-type 1: its plasma determinants and relation with cardiovascular risk. Thromb Haemost 2004; 91: 861-872.

37 Perusse L, Despres JP, Lemieux S, Rice T, Rao DC, Bouchard C. Familial aggregation of abdominal visceral fat level: results from the Quebec family study. Metabolism 1996; 45: 378-382.

38 Hamsten A, Wiman B, de Faire U, Blombäck M. Increased plasma levels of a rapid inhibitor of tissue plasminogen activator in young survivors of myocardial infarction. $N$ Engl J Med 1985; 313: 1557-1563.

39 Thogersen AM, Jansson JH, Boman K, et al. High plasminogen activator inhibitor and tissue plasminogen activator levels in plasma precede a first acute myocardial infarction in both men and women: evidence for the fibrinolytic system as an independent primary risk factor. Circulation 1998; 98: 2241-2247.

40 Ye Z, Liu EH, Higgins JP, et al. Seven haemostatic gene polymorphisms in coronary disease: meta-analysis of 66,155 cases and 91,307 controls. Lancet 2006; 367: 651-658.

41 Tsantes AE, Nikolopoulos GK, Bagos PG, et al. Plasminogen activator inhibitor-1 4G/5G polymorphism and risk of ischemic stroke: a meta-analysis. Blood Coagul Fibrinolysis 2007; 18: 497-504.

42 Tsantes AE, Nikolopoulos GK, Bagos PG, et al. Association between the plasminogen activator inhibitor- $14 \mathrm{G} / 5 \mathrm{G}$ polymorphism and venous thrombosis. A meta-analysis. Thromb Haemost 2007; 97: 907-913.

43 Boekholdt SM, Bijsterveld NR, Moons AH, Levi M, Buller HR, Peter RJ. Genetic variation in coagulation and fibrinolytic proteins and their relation with acute myocardial infarction: a systematic review. Circulation 2001; 104: 3063-3068.

44 Suzuki J, Ogawa M, Muto S, et al. Effects of specific chemical suppressors of plasminogen activator inhibitor-1 in cardiovascular diseases. Expert Opin Investig Drugs 2011; 20: 255-264.

45 Wang B, Zhou X, Dang A, Liu G, He R. Alu-repeat polymorphism in the gene coding for tissue-type plasminogen activator and the risk of hypertension in a Chinese Han population. Hypertens Res 2002; 25: 949-953. 